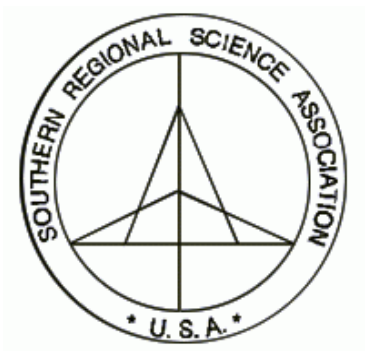

The Review of Regional Studies

Oklahoma State University

\title{
State and Local Policy, Factor Markets, and Regional Growth*
}

\author{
Stephen P.A. Brown \\ Research Department, Federal Reserve Bank of Dallas \\ Dallas, TX75265, email: stephen.p.brown@dal.frb.org \\ Kathy J. Hayes \\ Department of Economics, Southern Methodist University \\ Dallas, TX75265,email: khayes@mail.smu.edu \\ Lori L. Taylor \\ Research Department, Federal Reserve Bank of Dallas \\ Dallas,TX75265,email:lori.l.taylor@dal.frb.org
}

\begin{abstract}
A large and growing literature has developed to explain how state and local policies affect factor markets, firm location, and economic growth; but it has emerged in three distinct threads. These threads have variously emphasized how policy and natural amenities affect regional economic growth, employment growth, or firm location; how variations in policy and natural amenities can lead to persistent wage differentials across regions; and how regional variation in factor inputs, including public capital, affects output. In this article, we expand the modeling framework of Roback and Gyourko and Tracy to integrate these threads into a single inquiry about how state and local policies - including the provision of public capital — affect factor markets and economic growth.
\end{abstract}

\footnotetext{
*The authors thank Katharine Bradbury, Mark Partridge, and Alan Schlottmann for their comments on earlier drafts. The views expressed are those of the authors and should not be attributed to the Federal Reserve Bank of Dallas, the Federal Reserve System, or Southern Methodist University.
} 


\section{INTRODUCTION}

State and local governments are an important source of economic policy in the United States. The extent to which these policies affect private factor markets determines the extent to which state and local government influences employment, industry composition, and economic growth. Therefore, a large and growing economics literature has developed to explain how state and local policies affect factor markets, firm location, and economic growth.

To some extent, however, the literature has divided into three relatively distinct threads. One thread of the literature examines how state and local policy and natural amenities affect regional economic growth or firm location (e.g,. Carlino and Mills 1985; Bartik 1985 and 1988; Carlton 1983; Papke 1991; and Gray 1997). Another thread emphasizes how differences in state and local policy and natural amenities can lead to persistent regional differentials in wage rates (e.g., Roback 1982; Beeson and Eberts 1989; Gyourko and Tracy 1989; and Haughwout 2002). The third thread examines whether the United States has sufficient public capital by examining how regional variation in factor inputs affects regional output (e.g., Aschauer 1989; Munnell 1990; Holtz-Eakin 1994; Bartik 1996; Garcia-Milà; McGuire, and Porter 1996; Morrison and Schwartz 1996; Kelejian and Robinson 1997; Boarnet 1998; Button 1998; Fernald 1999; and Puig-Junoy 2001).

In this article, we expand the modeling framework of Roback (1982) and Gyourko and Tracy (1989) to draw together the three threads of previous inquiry into a single inquiry of how state and local policy - including the provision of public capital - affects factor quantities and, consequently, economic growth. Econometric implementation of the model involves two steps. The first step is to estimate how state and local policy and natural amenities affect private capital and labor in a state. The second step is to estimate how private and public capital and labor contribute to state economic growth, while allowing private capital and labor to respond endogenously to the other variables in the model. ${ }^{2}$

Estimation of the model allows us to examine how state and local policies - including the provision of public capital — affect private factor quantities and economic growth. Our analysis addresses an empirical avenue in the debate on whether public capital is under provided that was first identified by Garcia-Milà, McGuire, and Porter (1996) and has remained largely unexplored. We find that state and local policies have a more profound influence on the private capital-to-labor ratio in a region than on private output. Furthermore, the evidence suggests that growth of government - whether it be in terms of services or infrastructure - appears to discourage growth of the private sector.

\section{AN EQUILIBRIUM MODEL OF FACTOR MARKETS}

A general equilibrium model of factor markets provides insight into the various types of government influence. We model activity in the land, labor, and capital markets as arising from the interaction between workers and firms taking as given government activity and allowing for differentials in unemployment between jurisdictions. The representative individual seeks to

\footnotetext{
2 The model's reduced form provides a theoretical foundation for much of the existing literature relating state and local policy to variations in regional growth.
} 
maximize utility in the jurisdictional choice and, when employed, sells one unit of labor at the market wage. The representative firm takes prices as given and seeks to maximize profits. By assumption, the representative agent is free to move among jurisdictions but must work, consume, and pay taxes in his chosen jurisdiction.

The representative individual's utility can be described as:

$$
U=U\left(q, N, L, A_{j}, G_{j}\right)
$$

where $q$ is the quantity of goods consumed by the representative individual, $N$ is the quantity of land consumed by the representative individual, $L$ is quantity of labor supplied and equals unity if the worker is employed and zero if the worker is unemployed, $A_{j}$ is a vector of natural amenities found in jurisdiction $j$, and $G_{j}$ is a vector of state and local government services provided in jurisdiction $j$ including public capital.

The representative individual's budget constraint is:

$$
P\left(1+\tau_{s j}\right) q+n_{j}\left(1+\tau_{n j}\right) N=w_{j} L_{j}\left(1-\tau_{w j}\right)+I\left(1-\tau_{i j}\right)
$$

where $P$ is the national price of good $q, \tau_{s j}$ is the sales tax in jurisdiction $j, n_{j}$ is the rental rate for land in jurisdiction $j, \tau_{n j}$ is the land rental tax rate imposed by state and local governments in jurisdiction $j, w_{j}$ is the wage rate in jurisdiction $j, \tau_{w j}$ is the labor income tax rate imposed by state and local governments in jurisdiction $j, I$ is nonlabor income, and $\tau_{i j}$ is the tax rate on nonlabor income imposed by the government in jurisdiction $j$.

Combining equations 1 and 2 with the unemployment rate for jurisdiction $j$ yields an expression for indirect utility:

(3) $V_{j}=V\left(w_{j}\left(1-\tau_{w j}\right), \Upsilon_{j}, I\left(1-\tau_{i j}\right), P\left(1+\tau_{s j}\right), n_{j}\left(1+\tau_{n j}\right), A_{j}, G_{j}\right)$.

For a representative individual, utility in jurisdiction $j$ is a function of the after-tax wage rate; the unemployment rate $\left(\Upsilon_{j}\right)$; after-tax nonlabor income; the tax-inclusive price of goods; the taxinclusive rental rate on land, natural amenities, and the provision of government services. Our inclusion of the unemployment rate in the indirect utility function represents a potentially important departure from the approaches taken by Roback (1982) and Gyourko and Tracy (1989). Its inclusion allows for Neumann and Topel's (1991) finding that regional variation in unemployment rates and wages can be persistent and explained in equilibrium. ${ }^{3}$

Labor mobility assures equal (constant) expected utility across jurisdictions in the long run:

$$
V_{j}=\bar{V}
$$

Production in each jurisdiction can be described as:

\footnotetext{
3 Also see Harris and Todaro (1970).
} 


$$
Q_{j}=Q\left(L_{j}, K_{j}, N_{j}, A_{j}, G_{j}, R_{j}\right),
$$

where $Q_{j}$ is the output of the good in jurisdiction $j, L_{j}$ is the quantity of labor employed in jurisdiction $j, K_{j}$ is the quantity of private capital used in jurisdiction $j, N_{j}$ is the quantity of land used for production in jurisdiction $j$, and $R_{j}$ is a vector of state and local regulation in jurisdiction $j$. Because all workers in the jurisdiction sell one unit of labor, $L_{j}\left(1+\Upsilon_{j}\right)$ is the number of residents in jurisdiction $j$.

Firms in jurisdiction $j$ maximize profits as follows:

$$
\max \pi_{j}^{*}=P \cdot Q_{j}-w_{j} L_{j}-r_{j}\left(1+\tau_{r j}\right) K_{j}-n_{j}\left(1+\tau_{n j}\right) N_{j},
$$

where $r_{j}$ is the rate of return on capital in jurisdiction $j$ and $\tau_{r j}$ is the tax rate on capital.

Combining equations (5) and (6) yields an indirect profit function for production in jurisdiction $j$ :

$$
\pi_{j}^{*}=\pi^{*}\left(P, w_{j}, r_{j}\left(1+\tau_{r j}\right), n_{j}\left(1+\tau_{n j}\right), A_{j}, G_{j}, R_{j}\right) .
$$

Profits in jurisdiction $j$ are a function of the price of goods sold, wages (inclusive of taxes), the rate of return on capital, the tax inclusive rental rate on land, natural amenities, state and local government services, and state and local regulation.

Capital mobility assures that the after-tax rate of return is equalized across jurisdictions in the long run. Therefore,

$$
r_{j}=r,
$$

where $r$ is the national rate of return on capital. The quantities of capital used in each jurisdiction will adjust until any regional variation in the before-tax rate of return to capital reflects only state and local taxes on capital.

The free entry and exit of firms assures that economic profits are reduced to zero over the long run:

$$
\pi_{j}^{*}=0
$$

Following Gyourko and Tracy (1989) each pair of equations (3) and (4), and (7) and (9) can be solved for the tax inclusive rental price of land, $n_{j}\left(1+t_{n j}\right)$. Combining the resulting expressions yields a reduced form equation for the long-run equilibrium wage rate in each jurisdiction:

$$
w_{j}=w\left(\tau_{i_{j}}, \tau_{w_{j}}, \tau_{s_{j}}, \tau_{r_{j}}, P, r, I, A_{j}, G_{j}, R_{j}, \Upsilon_{j}\right) .
$$

As shown in equation (10), equilibrium wages in a jurisdiction are a function of tax rates on nonlabor income, wages, goods, capital, national prices for output and capital, nonlabor income, the 
jurisdiction's natural amenities, government services, government regulations, and the unemployment rate. In long-run equilibrium, differences in wages represent compensating differentials for differences in the right-hand-side variables, and equation (10) serves as the basis for the empirical literature attempting to explain persistent variation in wages across regions. As shown, regional variations in land tax rates are capitalized into land values and do not affect wages.

Similarly, one can combine the four equations to yield a reduced-form equation for the long-run equilibrium rental price of land:

$$
n_{j}=n\left(\tau_{I_{j}}, \tau_{w_{j}}, \tau_{n_{j}}, \tau_{s_{j}}, \tau_{r_{j}}, P, r, I, A_{j}, G_{j}, R_{j}, \Upsilon_{j}\right) .
$$

As shown by equation (11), wage tax rates are capitalized into land values, even though regional variations in property tax rates are not reflected in wages. Because land is immobile, its price reflects all the aspects of the jurisdiction, including policy.

Given these long-run equilibrium equations for factor prices and a well-behaved production function (equation 5), we follow Haughwout (1998) to obtain reduced-form equations for factor quantities. ${ }^{4}$

$$
\begin{aligned}
& L_{j}=L\left(\tau_{i_{j}}, \tau_{s_{j}}, \tau_{n_{j}}, \tau_{r_{j}}, \tau_{w_{j}}, P, r, I, A_{j}, G_{j}, R_{j}, \Upsilon_{j}\right) \\
& K_{j}=K\left(\tau_{i_{j}}, \tau_{s_{j}}, \tau_{n_{j}}, \tau_{r_{j}}, \tau_{w_{j}}, P, r, I, A_{j}, G_{j}, R_{j}, \Upsilon_{j}\right) \\
& N_{j}=N\left(\tau_{i_{j}}, \tau_{s_{j}}, \tau_{n_{j}}, \tau_{r_{j}}, \tau_{w_{j}}, P, r, I, A_{j}, G_{j}, R_{j}, \Upsilon_{j}\right)
\end{aligned}
$$

These three equations for factor quantities provide a basis for estimating the effects on factor markets; and similar forms to equations (12) and (13) have been used in some of the empirical literature on the effects of state and local policy on regional economic growth, but without formal derivation and without the inclusion of public capital as a government service. Some of these models have been made more interesting by introducing related dynamics such as population growth (e.g., Carlino and Mills 1985).

For each jurisdiction, labor, capital, and land depend on the same set of variables: the nationally determined prices for output and capital, nonlabor income, local amenities, the local unemployment rate, and the full spectrum of state and local governmental policies. One striking feature of the set of equilibrium conditions is the pervasive effect of government policies. A government's choices concerning tax rates have repercussions beyond the market in which the tax is levied. For example, although sales taxes are levied only on the consumption of output, they can distort all dimensions of the factor markets except for the price of capital. Similarly, wage taxes influence not only the labor market but also the quantities of capital and land used in production.

\footnotetext{
${ }^{4}$ In this context, a well-behaved production function supports a technology set that is a nonempty closed convex set with freely disposable inputs and outputs (for further discussion, see Fare and Primont 1995).
} 


\section{OUTPUT}

Substituting equations (12), (13), and (14) into the production function (5) yields a reduced form relating state and local fiscal policy, the provision of public capital, natural amenities, government regulation, and other variables to output:

$$
Q_{j}=Q\left(\tau_{i_{l}}, \tau_{s_{j}}, \tau_{n_{j}}, \tau_{r_{j}}, \tau_{w_{j}}, P, r, I, A_{j}, G_{j}, R_{j}, \Upsilon_{j}\right) .
$$

Similar forms to equation (15) have been used in the empirical literature on the effects of state and local policy on regional economic growth without formal derivation and without the inclusion of public capital as a government service. Some output models have been made more interesting by introducing related dynamics such as the development of innovative capacity (e.g., Riddel and Schwer, 2003).

An alternative strategy is to estimate the production function as it is originally written while recognizing that the quantities of private capital and labor are endogenous and must be instrumented: ${ }^{5}$

$$
Q_{j}=Q\left(\hat{L}_{j}, \hat{K}_{j}, N_{j}, A_{j}, G_{j}, R_{j}\right) .
$$

The right-hand-side variables in equations (12) and (13) provide convenient instruments for labor and private capital. Similar forms to equation (16) have been used in the empirical literature on whether the United States has sufficient public capital without instrumenting labor and private capital and without the inclusion of state and local government services other than public capital. ${ }^{6}$

\section{EMPIRICAL ANALYSIS}

Equations (12) and (13) provide a basis for estimating the effects of public capital, as well as state and local expenditures and taxes on the private capital and labor in a state. Equations (15) and (16) provide two differing estimation strategies for determining how public capital and state and local fiscal policy affect output. We explore these approaches using a panel of state-level data for the 48 contiguous U.S. states from 1977-1997. First, we estimate equations (12), (13), and (15). Second, we estimate equation (16) using the right-hand-side variables from equations (12) and (13) as the instruments for private capital and labor. We find that the growth of government is not associated with faster growth of the private sector. On the contrary, the growth of government - whether it be services or infrastructure - appears to discourage growth of the private sector.

\footnotetext{
5 Some may regard the quantity of land as endogenous in an economic sense, but available data make it an exogenous variable that is time invariant and captured as state-level fixed effects.

${ }^{6}$ In a somewhat different approach, Pereira (2001) examines impulse responses obtained from simulations of a vector autoregressive model with equations representing output, private employment, private investment, and various measures of public capital investment. This approach necessitates the omission of other measures of state and local policy.
} 


\subsection{Data}

Alicia Munnell's data (Munnell 1990) are frequently used to examine productivity and economic growth (e.g., Morrison and Schwartz 1996; Kelejian and Robinson 1997), but her estimates of private capital stock leave room for improvement. Munnell decomposes U.S. estimates of private capital into state-level estimates using information from industry censuses to identify each state's share of U.S. capital for that industry in census years. She then assumes that the state shares of private capital are constant for a multi-year period centered on the census year. "Data from the 1972 Census were used to apportion among the states the BEA national stock estimates for 1969 to 1974; 1977 shares were used for the 1975 to 1979 stock estimates; 1982 shares were the basis for the estimates from 1980 to 1984 and 1987 data were used to apportion national asset totals for 1985 and 1986" (Munnell 1990, p. 97). Thus, the private capital stocks in each industry in a state are assumed to grow at the national rate in most years. Private capital stocks in each industry in a state are assumed to grow at rates different than the national rate only during the one-year intervals from 1974 to 1975,1979 to 1980 , and 1984 to 1985.

Munnell's apportionment strategy has unfortunate consequences for the temporal patterns of growth of the private capital stocks in each state. In 1975, 1980, and 1985, growth rates are exaggerated in each industry to "catch up" for the five-year deviations in the state's growth rate from the national average. In all other years, the cross-sectional variations in the growth of private capital arise solely from changes in the industrial composition of the states.

We improve on Munnell's private capital data in three ways. First, rather than assume that state capital stocks grow at the national rate in most years, we use an interpolation strategy that accounts for the differential between state and national growth over each interval. Our interpolation strategy allows each industry's capital stock to grow at a state-specific ratio to the U.S. growth rate for that industry. Second, we base our estimates on improved measures of the U.S. capital stock that were not available to Munnell. Finally, we update Munnell's series to cover the period 1967-1997. (See the appendix for further details on the construction of the private capital stock series.)

We also construct a public capital series covering the period 1967-1997 using an approach that is similar to Munnell's. We estimate net public capital stocks for each state by apportioning the Bureau of Economic Analysis (BEA) national estimates for state and local government capital. Following Munnell, we use annual data on government capital outlays since 1958 to generate perpetual-inventory estimates of public capital stocks for each state. We sum these estimates across the states and assign each state a share of the national public capital stock according to its share of the sum-of-states estimate. As in Munnell, the analysis yields capital stock estimates for highways, sewers, and water supply systems and total state and local government capital.

We differ from Munnell in several ways, however. We have incorporated improved estimates of national public capital stocks that were not available to Munnell. In addition, where Munnell assumed that the composition of the public capital stock was stable through time, we accommodate the shift toward assets with shorter service lives by using the implicit national depreciation rate when calculating perpetual inventory estimates for the states. (See the appendix for further details on the construction of the public capital stock series.) 
The remaining data in the panel come from a variety of sources. Data on unemployment rates, private real gross state product, and private employment in each state come from the Bureau of Labor Statistics and the BEA. Data on taxes and other characteristics of the state fiscal environment come from the Census and Survey of Governments. We construct proxies for effective tax rates by dividing state and local government revenues from sales, property, individual income, and corporate income by gross state product. All other components of the government budgets are also deflated by gross state product to facilitate a balanced-budget interpretation. Those other components include net transfers from the federal government; net revenues from utilities; charges for higher education; other general user fees and expenditures on higher education, elementary and secondary education, health and hospitals, transfers, transportation, environment (natural resources, parks, and recreation), housing (housing and community development, sewerage and solid waste management), public

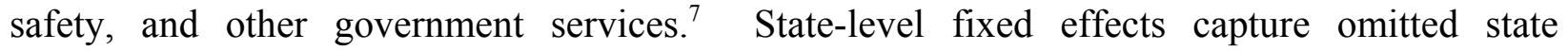
characteristics, while time fixed effects capture national business cycle variations.

For purposes of estimation, capital, labor, and output are transformed into log first differences, while the remaining variables - tax rates, spending rates, and unemployment rates - are expressed as first differences. ${ }^{8}$ To allow for diminishing returns to the size of the public sector, we also include a measure of government size (direct operating expenditures as a share of GSP in levels). Following Garcia-Milà, McGuire and Porter (1996), we lag all of the independent variables one year so that they are at least nominally predetermined. Because consistent data on real gross state product are only available since 1977, our analysis covers the period 1979-1997.

\subsection{Reduced-Form Estimation}

Our first approach is to estimate equations for capital (12), labor (13), and the reduced form equation for output (15). To improve the efficiency of estimates from a panel with a short time series and many cross sections, we use the block-diagonal covariance structure suggested by Gunther and Schmidt (1993). Because the Gunther-Schmidt approach allows for correlation among the residuals for all states within a designated group, it can also capture some of the spatial correlation among states. ${ }^{9}$ We use the SAS CLUSTER procedure to cluster states into eight groups according to industrial mix (see Appendix Table A1). ${ }^{10}$ We note that clustering the states according to the nine major census regions yields qualitatively similar results (see Appendix Table A2).

7 The omitted category is miscellaneous revenues and deficit spending. Expenditures on elementary and secondary education and on health and hospitals are expressed net of user fees. The school lunch program is the primary source of user fees in elementary and secondary education. Elementary and secondary education includes educational services not elsewhere classified.

8 For ease of exposition, we also multiply all of these variables by 100 .

9 We also adjust each equation for state-specific temporal autocorrelation using Cochrane-Orcutt Iterative Least Squares to estimate the autocorrelation coefficient. Estimated autocorrelation coefficients range from -.51 to .85 for the employment equation, .56 to .95 for the private capital equation, and - .63 to .83 for the gross state product equation.

${ }^{10}$ Our measures of industrial mix are the shares of GSP in each major industry group in the state-agriculture, mining, construction, manufacturing, retail trade, wholesale trade, TCPU (transportation, communications, and public utilities), services, FIRE (finance, insurance, and real estate), and government. 
Government expenditures and taxation variables enter the estimation symmetrically with a balanced-budget constraint. Thus, the coefficient on a tax or revenue variable reflects the effects of faster growth in that budget component while holding constant the growth in all other included budget components. This means that the revenue and expenditure variables are evaluated against a change in the omitted variable. The selection of the omitted variable is key to interpreting the results. If the omitted variable represents a particularly attractive source of revenue, the coefficients on expenditures and most other revenue sources will be negative.

In the reported tables, the omitted variable is miscellaneous revenues and deficit spending. Thus, the property tax coefficient would be interpreted as the impact of faster growth in property taxes financed by slower growth in miscellaneous revenues and deficit spending. Similarly, the coefficient on the health and hospitals variable would be interpreted as faster growth in health expenditures financed by faster growth in miscellaneous revenues. If we wish to determine the impact of faster growth in expenditures on health and hospitals financed by property taxes, we simply add the coefficients together.

Table 1 presents the coefficient estimates and standard errors for equations (12), (13), and (15). Table 2 summarizes the balanced-budget evidence on public services and taxes to support those services. In Table 2, a "+" indicates a significantly positive coefficient on the joint hypothesis of an increase in the given form of public spending, financed by an increase in the designated tax; a "_" indicates a significantly negative coefficient; and a blank indicates a coefficient that is insignificant at the 5 percent level. As such, a "-" likely indicates a service that is over provided, a "+" a service that is under provided, and a blank a service that is optimally provided in the average state. ${ }^{11}$

Tables 1 and 2 support a number of interesting observations. First, states where public capital stocks are growing rapidly tend to experience less private sector growth than other states. None of the types of public capital are positively associated with growth in the private factors of production or with rising private sector output. Growth in highway capital and water and sewer capital is significantly negative in all three equations. Growth in other public capital also has a significantly negative relationship with private employment and output.

Second, few public services appear to be systematically under provided. ${ }^{12}$ There is no combination of rising taxes and rising public spending that is positively associated with growth in private capital. Faster growth in transportation services appears to enhance private employment growth, but only if it is financed by sales or income taxes (or cuts in other public services).

11 For a service that is underprovided (overprovided), the marginal value of additional service is greater (less) than the marginal economic cost of additional tax, and the estimated coefficient is positive (negative). For a service that is optimally provided, the marginal value of additional service just offsets the marginal economic cost of additional tax, and the coefficient is zero.

12 A principal difference between our estimates and those in the previous research (such as Helms 1985) that examined the economic effects of state and local budgetary policy is our simultaneous inclusion of variables representing public capital and state and local government expenditures and revenues. As Appendix Table A3 illustrates, however, our estimates for the expenditure and revenue variables are generally insensitive to the exclusion of the public capital variables. 
Transportation services and to a lesser extent housing and sanitation appear associated with faster output growth, but not if they are financed through sales taxes. Private capital is attracted to states where higher education spending is growing, but only if it is financed through tuition charges; higher education spending financed by taxes is generally unattractive.

\section{TABLE 1}

The Effects of Policy Change on Economic Growth

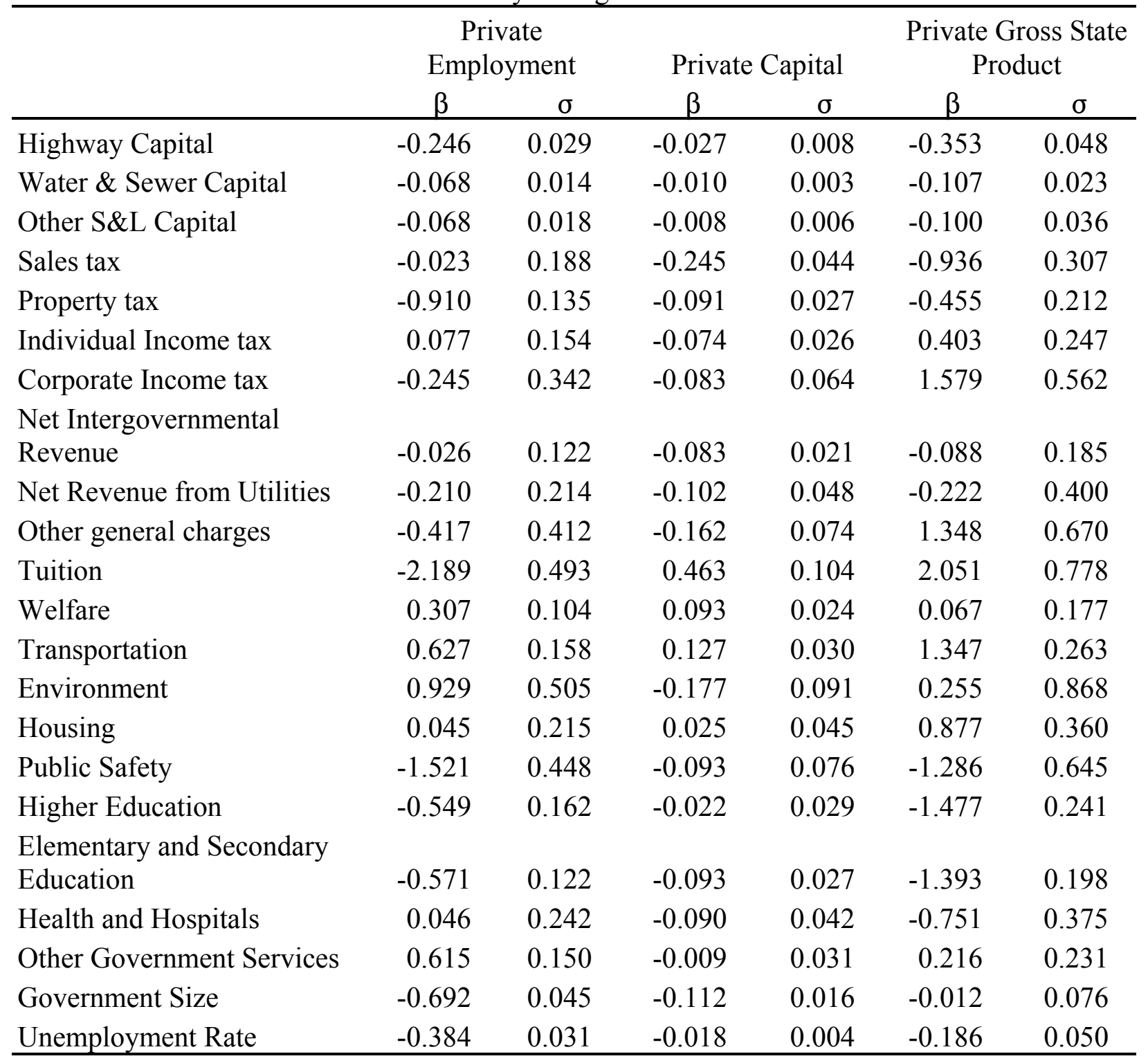

Adjusted R-square

0.8528

0.6542

0.7164

Note: All of the equations also include time and state fixed effects. 
If anything, most public services do not appear to justify the taxes needed to finance them. Any tax savings financed by slower growth in environmental services, health and hospitals, or elementary and secondary education is positively associated with growth in private capital. Similarly, any tax savings financed by slower growth in public safety or education spending is positively associated with growth in private employment.

On the revenue side, labor strongly favors states with growing sales taxes over states with growing property taxes. In fact, rising property taxes are particularly unattractive to labor. Almost any spending cut or revenue increase that would slow the growth of property taxes is associated with faster growth in private employment. ${ }^{13}$

On the other hand, private capital strongly disfavors rising sales taxes. A budgetary reallocation that substituted income or property taxes for sales taxes would be associated with significantly faster accumulation of private capital, as would any spending cut that slowed the growth of sales taxes.

To a large extent, the effects that public capital and state and local fiscal policy have on private output reflect the effects on capital and labor. Some state and local government expenditures more than justify the taxes used to support them. Most do not. ${ }^{14}$

Nonetheless, the effects of government policy on output are not just a weighted average of the factor market effects. For example, the private capital and labor equations strongly suggest that large governments deter factor accumulation - the coefficient on government size is negative and highly significant in both factor equations - but government size is insignificant in the reduced-form output equation. These findings raise the possibility that the government can both crowd out and substitute for private capital and labor.

\subsection{Instrumental Variables Estimation}

Our second approach to estimating the effects of state and local policy on private output is to estimate equation (16) using instrumental variables. The effects of state and local policy on private factors are captured in the auxiliary equations. Therefore, the coefficients on state and local capital and fiscal policy in the primary equation should reflect only direct productivity effects and not those operating indirectly through the factor markets.

We estimate equation (16) using the right-hand-side variables from equations (12) and (13) as the instruments for private capital and labor. Because the residuals from (12) and (13) are correlated, we use three-stage least squares. The data are adjusted using the same autocorrelation coefficients as in the reduced-form output equation. State fixed effects on output are not included in the primary equation for output, although they are included in both of the auxiliary equations.

13 One possible explanation is that rising property tax revenues may reflect rising property values and a generally rising cost of living, which would discourage in-migration.

14 This finding departs somewhat from the earlier literature, which showed that growth of most state and local government expenditures would have a favorable effect on economic growth. Taylor and Brown (2002) suggest that the difference from the earlier literature likely reflects the substantial increase in state and local government expenditures that occurred during the 1980s. 


\section{TABLE 2}

The Joint Effects of Taxes and Spending

\begin{tabular}{|c|c|c|c|c|c|c|c|c|c|c|c|c|}
\hline & \multicolumn{4}{|c|}{ Private Employment } & \multicolumn{4}{|c|}{ Private Capital } & \multicolumn{4}{|c|}{ Private Output } \\
\hline & $\frac{\infty}{\tilde{N}}$ & $\begin{array}{l}\text { D্ं } \\
0 \\
0 \\
0 \\
0\end{array}$ & $\begin{array}{l}\mathscr{E} \\
\tilde{\delta} \\
\Xi \\
\end{array}$ & 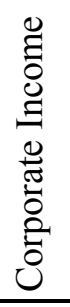 & $\frac{\mathscr{e}}{\tilde{N}}$ & 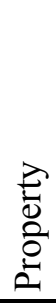 & $\begin{array}{l}\mathscr{E} \\
\tilde{0} \\
\Xi \\
\end{array}$ & 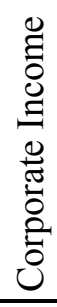 & $\frac{\mathscr{e}}{\tilde{N}}$ & 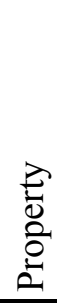 & $\begin{array}{l}\mathscr{E} \\
\tilde{O} \\
\Xi \\
\end{array}$ & 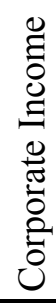 \\
\hline Welfare & & - & + & & - & & & & - & & & + \\
\hline Transportation & + & & + & & - & & & & & + & + & + \\
\hline Environment & & & & & - & 一 & 一 & 一 & & & & \\
\hline Housing & & - & & & - & & & & & & + & + \\
\hline Public Safety & - & - & 一 & 一 & - & 一 & & & 一 & 一 & & \\
\hline Higher Education & - & - & 一 & 一 & - & 一 & 一 & & 一 & 一 & 一 & \\
\hline $\begin{array}{l}\text { Elementary and } \\
\text { Secondary Education }\end{array}$ & - & - & - & - & - & - & - & - & - & - & - & \\
\hline Health and Hospitals & & - & & & - & - & - & - & - & - & & \\
\hline $\begin{array}{l}\text { Other Government } \\
\text { Services }\end{array}$ & + & & + & & - & - & 一 & & & & & + \\
\hline
\end{tabular}

“-" indicates significantly negative at the 5 percent level, while "+" indicates significantly positive.

Table 3 compares the reduced-form estimates of the output equation (15) with the estimates for the output equation obtained with three stage least squares (3SLS). The 3SLS estimates show that an increase in private capital or labor increases private output. Government services are significant in the reduced-form estimation but generally insignificant in the 3SLS estimation. The hypothesis that all of the coefficients on the government services variables in the 3SLS equation are jointly zero cannot be rejected at any traditional level of significance. Therefore, the analysis suggests that government services influence output growth primarily through their influence on factor accumulation.

The previous literature suggests that increased provision of public capital is unlikely to reduce gross state product directly (Garcia-Milà, McGuire and Porter 1996), and indeed we find that increases in public highways and water and sewer capital have no effect on the growth of private output beyond their effects on private capital and labor. However, we also find that an increase in other state and local public capital has a significantly negative effect on private output growth, holding constant private capital and labor and spending on public services. Taken at face value, this finding would seem to imply that other state and local public capital has been increased to the point of negative returns, perhaps because a growing stock of other public capital is indicative of an 
increasingly intrusive government. Alternatively, the negative coefficient could imply that unproductive public capital consumes resources that otherwise would be used to provide productive public services.

\section{TABLE 3}

Policy and the Growth in Private Gross State Product

\begin{tabular}{|c|c|c|c|c|}
\hline & \multicolumn{2}{|c|}{ Reduced-Form Estimation } & \multicolumn{2}{|c|}{ 3SLS Estimation } \\
\hline & $\beta$ & $\sigma$ & $\beta$ & $\sigma$ \\
\hline Private Capital & . & . & 0.442 & 0.128 \\
\hline Private Employment & . & . & 0.611 & 0.128 \\
\hline Highway Capital & -0.353 & 0.048 & -0.124 & 0.082 \\
\hline Water \& Sewer Capital & -0.107 & 0.023 & -0.047 & 0.039 \\
\hline Other S\&L Capital & -0.100 & 0.036 & -0.122 & 0.056 \\
\hline Sales tax & -0.936 & 0.307 & . & . \\
\hline Property tax & -0.455 & 0.212 & . & . \\
\hline Individual Income tax & 0.403 & 0.247 & . & . \\
\hline Corporate Income tax & 1.579 & 0.562 & . & . \\
\hline \multicolumn{5}{|l|}{ Net Intergovernmental } \\
\hline Revenue & -0.088 & 0.185 & . & . \\
\hline Net Revenue from Utilities & -0.222 & 0.400 & . & . \\
\hline Other general charges & 1.348 & 0.670 & . & . \\
\hline Tuition & 2.051 & 0.778 & . & . \\
\hline Welfare & 0.067 & 0.177 & 0.075 & 0.353 \\
\hline Transportation & 1.347 & 0.263 & 1.083 & 0.491 \\
\hline Environment & 0.255 & 0.868 & -0.639 & 1.494 \\
\hline Housing & 0.877 & 0.360 & 0.942 & 0.701 \\
\hline Public Safety & -1.286 & 0.645 & 0.731 & 1.433 \\
\hline Higher Education & -1.477 & 0.241 & -0.701 & 0.544 \\
\hline \multicolumn{5}{|l|}{ Elementary and Secondary } \\
\hline Education & -1.393 & 0.198 & -0.472 & 0.436 \\
\hline Health and Hospitals & -0.751 & 0.375 & -0.986 & 0.885 \\
\hline Other Government Services & 0.216 & 0.231 & 0.406 & 0.408 \\
\hline Government Size & -0.012 & 0.076 & 0.047 & 0.060 \\
\hline Unemployment Rate & -0.186 & 0.050 & 0.217 & 0.120 \\
\hline Adjusted R-square & \multicolumn{2}{|c|}{0.7164} & \multicolumn{2}{|c|}{0.5543} \\
\hline
\end{tabular}


Coupled with the equations for private labor and capital, the 3SLS results suggest that although the increased provision of public highways and water and sewer capital has no direct effect on private output growth, it reduces private output by deterring labor in-migration and private capital formation. Increased provision of other state and local public capital directly reduces output growth while it also discourages labor in-migration and has no apparent effect on private capital formation. In any case, however, we find the increased provision of public capital reduces the growth of private output.

\section{CONCLUSIONS}

Our analysis expands the modeling framework of Roback (1982) and Gyourko and Tracy (1989) to integrate into one what had previously been three distinct threads in the literature. One thread examines how state and local policy and natural amenities affect economic growth. Another thread examines how differences in state and local policy and natural amenities can lead to persistent differentials in wages across regions. A third thread examines whether the United States has sufficient public capital.

We use the modeling framework to examine how state and local fiscal policy and the provision of public capital affects the labor and private capital in a state and, consequently, its economic growth. Consistent with the previous literature, we find that some state and local government expenditures more than offset the negative effects of the taxes used to finance them. Most do not.

Consistent with Partridge and Rickman (2003), our analysis also suggests that private capital and labor grow most rapidly in states with smaller public sectors. We do not find that this effect carries over to private output, however. The size of state and local government appears to be neutral in its effect on private-sector output. Apparently a large public sector crowds out and substitutes for growth of private labor and capital.

We also find that the increased provision of public capital may discourage labor in-migration. According to the theoretical framework we employ, the discouraging effects on private labor inmigration arise through a crowding out and substitution of the public sector for the private sector - and not through capital inflows bidding up property values and increasing the cost of living, as we would conclude if public capital attracted private capital. In addition, some forms of state and local public capital have been increased to the point that (for the average state) further increases reduce private output. The net effect is that the increased provision of state and local public capital appears to reduce private gross state product - although total output may be higher.

These findings suggest why the political process may yield less public capital than might be preferred in some circles. Although the increased provision of public capital may boost total output in a jurisdiction, it apparently slows the growth of private sector output by discouraging private capital and labor in-migration, which would be indicative of lower rates of return and less utility. 


\section{APPENDIX}

In addition to the extended time-frame, our estimates of private capital stocks differ from Munnell's in two key respects. First, we differ because we use revised estimates of Fixed Reproducible Tangible Wealth that were not available to Munnell. Second, we use a different interpolation strategy for non-census years.

In census years, we follow Munnell in apportioning the U.S. capital stock to the states according to each state's share of economic activity in that industry. Wherever possible, a faithful replication and extension of Munnell's data was used to distribute the national capital stock estimates in census years. The shift to NAICS-based accounting for the 1997 census of services required considerable effort to construct consistently defined estimates for business services, personal services, auto-repair services, and amusements and motion pictures. When these series were unavailable on an SIC basis, an analog was constructed from the six-digit NAICS information.

To interpolate the state-level capital stocks in noncensus years, we calculate the rate of change between census years in the U.S. capital stock and the apportioned state-level capital stock for each industry. Let $\beta_{s}$ be the ratio of those rates of change.

Then $\beta_{s} / n$ would be the annualized differential in the growth rate over the $n$ year period. Assuming that state-level capital stocks grow at the national rate plus the state and industry-specific annualized differential $\left(\beta_{s} / n\right)$ then the state-level capital stocks in non-census years would be

This approach wedges back the differential in growth rates between the state and U.S. capital over intervals in which state data cannot be observed.

Our estimates of net public capital stocks also differ from Munnell's estimates in a number of ways. Most obviously, we have extended the data set to cover the period 1967-1997. We have also incorporated improved estimates of national public capital stocks that were not available to Munnell. Munnell followed the BEA by constructing net capital stocks presuming straight-line depreciation schedules and a modified Winfrey S-3 retirement pattern. More recently, however, the BEA has adopted a geometric depreciation strategy. To reflect the change in BEA techniques, we calculate our perpetual-inventory estimates of net capital stocks in each state for period $t$ as

$$
N_{t j}=\sum_{i=1}^{t} I_{i j}\left(1-\delta_{j} / 2\right)\left(1-\delta_{j}\right)^{t-i}
$$


where $t \geq I, N_{t j}$ is the net capital stock of asset type $j, I_{i j}$ is investment in year $I$, and $\delta_{j}$ is the annual geometric rate of depreciation for type of asset $j$ (U.S. Department of Commerce 1999). In turn,

$$
\delta_{j}=R_{j} / T_{j}
$$

where $T_{j}$ is the average service life for asset type $j$ in years and $R_{j}$ the declining balance rate for asset type $j$.

According to the BEA, the average service life for highways is 45 years, while the average service life for sewers and water supply systems is 60 years. The average service life for other types of state and local government capital ranges from seven years for typewriters and calculating machines to 80 years for new single-family residences. The declining balance rate $\left(R_{j}\right)$ is .91 for government structures and 1.65 for state and local government equipment. These figures imply that the annual geometric rate of depreciation is 0.0202 for highways, 0.0152 for water and sewer systems, and a function of the composition of net stocks for total public capital.

The implicit annual depreciation rate for the national estimate of aggregate state and local public capital has increased sharply since 1958, implying a large shift in composition over that period. To accommodate such a shift, we use this implicit depreciation rate in our calculations.

\section{TABLE A1}

State Clusters According to Industry Mix

1. GA, IL, KS, MN, MO, NJ, OR, TN

2. $\mathrm{AL}, \mathrm{AR}, \mathrm{IN}, \mathrm{KY}, \mathrm{ME}, \mathrm{MI}, \mathrm{MS}, \mathrm{NC}$, $\mathrm{NH}, \mathrm{OH}, \mathrm{PA}, \mathrm{SC}, \mathrm{VT}, \mathrm{WI}$

3. CA, CT, DE, MA, NY, RI

4. $\quad \mathrm{AZ}, \mathrm{CO}, \mathrm{FL}, \mathrm{MD}, \mathrm{UT}, \mathrm{VA}, \mathrm{WA}$

5. LA, MT, NM, OK, TX, WV

6. ID, IA, NE, ND, SD

7. WY

8. NV 
TABLE A2

The Effects of Policy on Growth: Clustered by Census

\begin{tabular}{lcccccc}
\hline & \multicolumn{2}{c}{ Private } & & \multicolumn{3}{c}{ Private Gross State } \\
& \multicolumn{2}{c}{ Employment } & \multicolumn{2}{c}{ Private Capital } & \multicolumn{2}{c}{ Product } \\
\hline Highway Capital & $\beta$ & $\sigma$ & $\beta$ & $\sigma$ & $\beta$ & $\sigma$ \\
Water \& Sewer Capital & -0.220 & 0.036 & -0.017 & 0.012 & -0.298 & 0.057 \\
Other S\&L Capital & -0.056 & 0.015 & -0.011 & 0.005 & -0.082 & 0.027 \\
Sales tax & -0.041 & 0.021 & 0.000 & 0.007 & -0.110 & 0.041 \\
Property tax & 0.068 & 0.201 & -0.128 & 0.063 & -1.194 & 0.337 \\
Individual Income tax & -0.875 & 0.155 & -0.036 & 0.039 & -0.416 & 0.262 \\
Corporate Income tax & 0.011 & 0.181 & -0.056 & 0.042 & 0.263 & 0.294 \\
Net Intergovernmental & 0.095 & 0.417 & -0.135 & 0.103 & 1.843 & 0.616 \\
Revenue & & & & & & \\
Net Revenue from Utilities & 0.098 & 0.138 & -0.014 & 0.034 & 0.161 & 0.234 \\
Other general charges & -0.353 & 0.221 & -0.048 & 0.055 & -0.156 & 0.385 \\
Tuition & -0.105 & 0.458 & -0.004 & 0.112 & 1.175 & 0.787 \\
Welfare & -3.718 & 0.601 & 0.284 & 0.157 & 1.969 & 1.157 \\
Transportation & 0.213 & 0.115 & 0.083 & 0.036 & 0.208 & 0.253 \\
Environment & 0.543 & 0.187 & 0.028 & 0.045 & 1.205 & 0.321 \\
Housing & 0.696 & 0.531 & -0.154 & 0.130 & -0.019 & 0.957 \\
Public Safety & 0.052 & 0.240 & 0.065 & 0.064 & 1.240 & 0.402 \\
Higher Education & -1.535 & 0.503 & -0.010 & 0.125 & -0.961 & 0.830 \\
Elementary and Secondary & -0.597 & 0.191 & 0.013 & 0.042 & -1.357 & 0.319 \\
Education & & & & & & \\
Health and Hospitals & -0.739 & 0.153 & -0.021 & 0.041 & -0.932 & 0.248 \\
Other Government Services & 0.331 & 0.291 & -0.105 & 0.066 & -1.163 & 0.512 \\
Government Size & -0.574 & 0.148 & -0.059 & 0.035 & 0.175 & 0.251 \\
Unemployment Rate & -0.369 & 0.050 & -0.125 & 0.025 & -0.054 & 0.092 \\
& & & & & & \\
Adjusted R-square & 0.8502 & -0.014 & 0.008 & -0.176 & 0.060 \\
\hline & & & 0.6497 & & 0.7130 \\
\hline
\end{tabular}

Note: All of the equations also include time and state fixed effects. 


\section{TABLE A3}

The Effects of Policy on Growth, Omitting Public Capital

\begin{tabular}{|c|c|c|c|c|c|c|}
\hline & \multicolumn{2}{|c|}{$\begin{array}{c}\text { Private } \\
\text { Employment }\end{array}$} & \multicolumn{2}{|c|}{ Private Capital } & \multicolumn{2}{|c|}{$\begin{array}{l}\text { Private Gross State } \\
\text { Product }\end{array}$} \\
\hline & $\beta$ & $\sigma$ & $\beta$ & $\sigma$ & $\beta$ & $\sigma$ \\
\hline Highway Capital & ${ }^{\circ}$ & . & . & . & . & . \\
\hline Water \& Sewer Capital & . & . & . & . & . & . \\
\hline Other S\&L Capital & & . & . & & & . \\
\hline Sales tax & -0.103 & 0.198 & -0.225 & 0.044 & -1.002 & 0.313 \\
\hline Property tax & -0.900 & 0.136 & -0.089 & 0.027 & -0.617 & 0.217 \\
\hline Individual Income tax & 0.139 & 0.154 & -0.073 & 0.025 & 0.373 & 0.257 \\
\hline Corporate Income tax & -0.371 & 0.343 & -0.094 & 0.062 & 0.889 & 0.552 \\
\hline $\begin{array}{l}\text { Net Intergovernmental } \\
\text { Revenue }\end{array}$ & -0.033 & 0.121 & -0.078 & 0.019 & -0.289 & 0.182 \\
\hline Net Revenue from Utilities & -0.090 & 0.228 & -0.089 & 0.045 & 0.072 & 0.392 \\
\hline Other general charges & -0.514 & 0.423 & -0.117 & 0.074 & 1.917 & 0.703 \\
\hline Tuition & -1.791 & 0.521 & 0.490 & 0.097 & 2.846 & 0.744 \\
\hline Welfare & 0.242 & 0.103 & 0.084 & 0.024 & 0.058 & 0.180 \\
\hline Transportation & 0.183 & 0.151 & 0.066 & 0.028 & 0.795 & 0.228 \\
\hline Environment & 0.899 & 0.505 & -0.172 & 0.088 & 0.206 & 0.847 \\
\hline Housing & -0.295 & 0.195 & -0.067 & 0.038 & 0.136 & 0.339 \\
\hline Public Safety & -1.909 & 0.446 & -0.035 & 0.076 & -1.674 & 0.614 \\
\hline Higher Education & -0.636 & 0.161 & -0.036 & 0.026 & -1.631 & 0.227 \\
\hline Elementary and Secor & & & & & & \\
\hline Education & -0.528 & 0.121 & -0.091 & 0.026 & -1.649 & 0.192 \\
\hline Health and Hospitals & 0.185 & 0.237 & -0.095 & 0.039 & -1.196 & 0.379 \\
\hline Other Government Services & 0.652 & 0.147 & -0.022 & 0.028 & 0.314 & 0.227 \\
\hline Government Size & -0.591 & 0.047 & -0.109 & 0.016 & 0.162 & 0.076 \\
\hline Unemployment Rate & -0.387 & 0.030 & -0.019 & 0.004 & -0.265 & 0.048 \\
\hline
\end{tabular}

Note: All of the equations also include time and state fixed effects. 


\section{REFERENCES}

Aschauer, D.A., 1989. “Is Public Expenditure Productive?” Journal of Monetary Economics 23, 177-200.

Bartik, T.J., 1985. "Business Location Decisions in the United States: Estimates of the Effects of Unionization, Taxes and Other Characteristics of States," Journal of Business and Economic Statistics 3 (January), 14-22.

, 1988. "The Effects of Environmental Regulation on Business Location in the United States," Growth and Change 19(3), 22-44.

, 1996. Growing State Economies: How Taxes and Public Services Affect Private-Sector Performance. Economic Policy Institute: Washington, D.C.

Beeson, P.E. and R.W. Eberts, 1989. "Identifying Productivity and Amenity Effects in Interurban Wage Differentials," Review of Economics and Statistics 71, 443-52.

Boarnet, M.G., 1998. "Spillovers and the Locational Effects of Public Infrastructure," Journal of Regional Science 38(3), 381-400.

Button, K., 1998. "Infrastructure Investment, Endogenous Growth and Economic Convergence," The Annals of Regional Science 32(1), 145-62.

Carlino, G. and E.S. Mills, 1985. "Do Public Policies Affect County Growth?” Federal Reserve Bank of Philadelphia Business Review (July-August), 3-27.

Carlton, D., 1983. "The Location and Employment Choices of New Firms: An Econometric Model with Discrete and Continuous Endogenous Variables," Review of Economics and Statistics 65 (August), 440-49.

Fare, R. and D. Primont, 1995. Multi-Output Production and Duality: Theory and Applications. Kluwer Academic Press: Boston and Dordrecht.

Fernald, J.G., 1999. "Roads to Prosperity: Assessing the Link between Public Capital and Productivity, American Economic Review 89(3), 619-38.

Garcia-Milà, T., T.J. McGuire, and R.H. Porter, 1996. "The Effect of Public Capital in StateLevel Production Functions Reconsidered," Review of Economics and Statistics 78 (February), 177-180.

Gray, W.B., 1997. "Manufacturing Plant Location: Does State Pollution Regulation Matter?" NBER Working Paper 5880. 
Grosskopf, S., K.J. Hayes, L.L. Taylor, and W.L. Weber, 2001. "On the Determinants of School District Efficiency: Competition and Monitoring," Journal of Urban Economics 49(3), 45378.

Gunther, J.W. and R.H. Schmidt, 1993. "Increasing the Efficiency of Pooled Estimation with a Block-Diagonal Covariance Structure," The Annals of Regional Science 27, 133-42.

Gyourko, J. and J. Tracy, (1989). "The Importance of Local Fiscal Conditions in Analyzing Local Labor Markets," Journal of Political Economy 97(5), 1208-31.

Harris, J.R. and M.P. Todaro, 1970. "Migration, Unemployment, and Development: A TwoSector Analysis," American Economic Review 60 (March), 126-42.

Haughwout, A.F., 1998. “Aggregate Production Functions, Interregional Equilibrium, and the Measurement of Infrastructure Productivity," Journal of Urban Economics 44, 216-27. , 2002. "Public Infrastructure Investments, Productivity and Welfare in Fixed Geographic Areas," Journal of Public Economics 83(3), 405-28.

Helms, F.J., 1985. "The Effects of State and Local Taxes on Economic Growth: A TimeSeries/Cross-Section Approach," Review of Economics and Statistics 67(November), 574-82.

Holtz-Eakin, D., 1994. "Public-Sector Capital and the Productivity Puzzle," Review of Economics and Statistics 76, 12-21.

Kelejian, H.H. and D.P. Robinson, 1997. "Infrastructure Productivity Estimation and Its Underlying Econometric Specifications: A Sensitivity Analysis," Papers in Regional Science 76(1), 115-31.

Morrison, C.J. and A.E. Schwartz, 1996. "State Infrastructure and Productive Performance," American Economic Review 86(5), 1095-1111.

Munnell, A.H., 1990. “How Does Public Infrastructure Affect Regional Economic Performance?” in A.H. Munnell (ed.), Is There a Shortfall in Public Capital Investment? Federal Reserve Bank of Boston: Boston.

Neumann, G.R. and R.H. Topel, 1991. "Employment Risk, Diversification, and Unemployment," Quarterly Journal of Economics 106 (November), 1341-65.

Partridge, M.D. and D.S. Rickman, 2003. "Do We Know Economic Development When We See It?” The Review of Regional Studies 33(1), 17-39.

Papke, L.E., 1991. "Interstate Business Tax Differentials and New Firm Location: Evidence From Panel Data," Journal of Public Economics 45(1), 47-68. 
Pereira, A.M., 2001. "On the Effects of Public Investment on Private Investment: What Crowds In What?" Public Finance Review 29(1), 3-25.

Puig-Junoy, J., 2001. "Technical Inefficiency and Public Capital in U.S. States: A Stochastic Frontier Approach,” Journal of Regional Science 41(1), 75-96.

Riddel, M. and R.K. Schwer, 2003. "Regional Innovative Capacity with Endogenous Employment: Empirical Evidence from the U.S.," The Review of Regional Studies 33(1), 7384.

Roback, J., 1982. "Wages, Rents and the Quality of Life," Journal of Political Economy 90 (December), 1257-78.

Taylor, L.L., 1995. “Allocative Inefficiency and Local Government,” Journal of Urban Economics, 37(2), 201-11.

and S.P.A. Brown, 2002. "The Growth of State and Local Government: Has More Become Bad?" Paper presented at the Western Economic Association Meeting, Seattle.

U.S. Department of Commerce, 1999. Fixed Reproducible Tangible Wealth in the United States, 1925-94, U.S. Government Printing Office: Washington, D.C. 